\title{
PELAKSANAAN PEMBELAJARAN TEMATIK DI SDN 1 KRAGILAN
}

\section{Bayu Purbha Sakti ${ }^{1}$, dan Sri Budiyono ${ }^{2}$}

${ }^{1,2}$ Universitas Widya Dharma Klaten

Email: bayups@unwidha.ac.id

\begin{tabular}{l}
\hline Info Artikel \\
\hline Sejarah Artikel: \\
Diserahkan 6 September 2019 \\
Direvisi 11 September 2019 \\
Disetujui 18 November 2019 \\
\hline Keywords: \\
thematic learning, hilly area, \\
elementary school
\end{tabular}

\section{Abstract}

The purpose of this study is to describe the implementation of thematic learning in SD N 1 Kragilan.

The research approach used is qualitative. The author determines SDN 1 Kragilan as a research location. Research data were collected by observation and interview techniques. Data analysis techniques used include the phase of data reduction, data display, and data verification.

The results showed that the teachers were able to understand thematic learning. Thematic learning is learning taught to children that combines several subjects put together in a theme. Thematic learning can take lessons from the natural surroundings and everyday life. The teachers have obstacles in carrying out thematic learning. The teachers find it difficult to run a thematic learning assessment system. Students are not yet accustomed to using thematic learning. The teachers already have a solution in thematic learning. The teachers exchange information, knowledge, and opinions with other teachers about thematic learning.

\begin{abstract}
Abstrak
Tujuan penelitian yaitu untuk mendeskripsikan pelaksanaan pembelajaran tematik di SD N 1 Kragilan.

Pendekatan penelitian yang digunakan adalah kualitatif. Penulis menentukan SDN 1 Kragilan sebagai lokasi penelitian. Data penelitian dikumpulkan dengan teknik observasi dan wawancara. Teknik analisis data yang digunakan meliputi fase reduksi data, penampilan data, dan verifikasi data.

Hasil penelitian menunjukkan bahwa para guru sudah bisa memahami pembelajaran tematik. Pembelajaran tematik adalah pembelajaran yang diajarkan ke anak yang memadukan dari beberapa mata pelajaran yang dijadikan satu dalam suatu tema. Pembelajaran tematik bisa mengambil pembelajaran dari alam sekitar dan kehidupan keseharian. Para guru memiliki kendala dalam melaksanakan pembelajaran tematik. Para guru merasa kesulitan dalam menjalankan sistem penilaian pembelajaran tematik. Para siswa belum terbiasa menggunakan pembelajaran tematik. Para guru sudah memiliki solusi dalam pembelajaran tematik. Para guru saling bertukar informasi, pengetahuan, dan pendapat dengan guru lain mengenai pembelajaran tematik.
\end{abstract}

C 2019 Universitas Muria Kudus 
Bayu Purbha Sakti dan Sri Budiyono

PELAKSANAAN PEMBELAJARAN TEMATIK DI SDN 1 KRAGILAN

REFLEKSI EDUKATIKA : Jurnal Ilmiah Kependidikan 10 (1) Desember 2019. Hlm. 65-70

\section{PENDAHULUAN}

Perkembangan zaman yang mulai memasuki kurikulum 2013 menuntut pembelajarannya sudah bersentra pada pembelajaran tematik yang menggabungkan antara mata pelajaran satu dengan pelajaran lainnya (Anshory, Saputra, dan Amelia, 2017). Penggabungan berbagai pelajaran tentunya akan menyulitkan para guru. Perubahan Kurikulum KTSP menjadi Kurikulum 2013 menghendaki lembaga pendidikan untuk melakukan perubahan secara terpadu, termasuk standar pendidik dan tenaga kependidikan, standar proses dan standar penilaian (Ahyar, Farida, dan Setiawati, 2016). Penggunaan pembelajaran tematik integratif, dalam kurikulum 2013 ini pendekaran pembelajaran yang digunakan adalah pendekatan scientific atau pendekatan ilmiah (Karyani, 2017). Pendekatan ilmiah ini juga membingungkan para guru jika mereka tidak mempelajarinya.

Penataran Kurikulum 2013 telah diselenggarakan pihak dinas pendidikan Kecamatan Prambanan dan diikuti oleh ratusan guru sekolah dasar dari Kecamatan Gantiwarno, Prambanan, Manisrenggo, Kemalang, Karangnongko, Klaten Selatan, Jogonalan, dan Kebonarum. Kepala Unit Pelaksana Teknis Dinas (UPTD) Pendidikan Kecamatan Prambanan Klaten, Mulyono mengatakan, penataran kurikulum 2013 yang diikuti ratusan guru SD meliputi Guru kelas 1, kelas 4 dan Guru Agama, yang diselenggarakan Dinas Pendidikan Klaten bekerjasama dengan Lembaga Penjamin Mutu Pendidikan (LPMP) Provinsi Jawa tengah (Mujiyono, 2016).

Beberapa sekolah dasar di Kecamatan Gantiwarno berdekatan dengan area perbukitan. Beberapa sekolah dasar di Kecamatan Gantiwarno mengalami kerusakan setelah terjadi gempa bumi pada tahun 2006. Sebanyak 15 SD akan dijadikan Sekolah Siaga Bencana (SSB) yang difokuskan merupakan sekolah yang ada di daerah rawan gempa, seperti Kecamatan Gantiwarno, Prambanan, Jogonalan, dan Wedi (Merdeka, 2017).

Berdasarkan data dari Kementerian Pendidikan dan Kebudayaan maka terdapat 24 sekolah dasar negeri yang terletak di Kecamatan Gantiwarno (Pendidikan, 2018). Penulis sudah melakukan observasi bahwa terdapat empat belas sekolah dasar negeri yang berada di Kecamatan Gantiwarno sudah melaksanakan Kurikulum 2013. Kurikulum ini dilaksanakan dengan kegiatan pembelajaran tematik. Beberapa sekolah dasar negeri yang menyelenggarakan pembelajaran tematik yaitu SDN 1 Kragilan, SDN 1 Towangsan, SDN 2 Jabung, SDN 1 Karangturi, SDN 1 Sawit, SDN 2 Ngandong, SDN Mutihan, SDN 1 Mlese, SDN 1 Baturan, SDN 2 Ceporan, SDN 2 Sawit, SDN Gesikan, SDN 1 Ngandong, dan SDN 2 Muruh. Pembelajaran tematik dibahas di 5 mata pelajaran yaitu Matematika, PKn, Bahasa Indonesia, IPA, dan IPS (Sakti \& Wijayanti, 2014). Oleh karena itu, para guru akan menemui kendala sebab mereka sebelumnya hanya mengajar satu pelajaran yang tidak dipadukan pada Kurikulum Tingkat Satuan Pendidikan.

Salah satu solusi bagi guru untuk memberikan kegiatan pembelajaran tematik yang mengeksplorasi yaitu dengan explore the voices of teachers in their own praxis as critical educators, with excerpts from their own lives and experiences as the basis for discussion within their respective works (Daniels, 2012). Maksudnya ialah menjelajahi suara guru dalam praksis mereka sendiri sebagai pendidik kritis, dengan kutipan dari kehidupan dan pengalaman mereka sendiri sebagai dasar untuk diskusi dalam karya masing-masing.

Guru sekolah dasar memiliki fungsi dan keahlian dalam menangani anak usia sekolah dasar (Sakti, 2017b). Pembelajaran yang dilaksanakan di sekolah dasar adalah pembelajaran tematik berdasarkan Kurikulum 2013. Belajar secara integrasi yang dilakukan anak usia sekolah dasar adalah belajar mengenai satu tema atau pokok pikiran (Sakti dan Wijayanti, 2014). Hal ini sejalan dengan penjelasan yaitu the establishment of thematic approach in lower elementary class by National Education Standards Board (BSNP) cannot be separated from the development of integrated learning concept (Narti, Setyosari, Degeng, dan Dwiyogo, 2016). Maksudnya ialah pembentukan pendekatan tematik di kelas dasar bawah oleh Badan Standar Nasional Pendidikan (BSNP) tidak dapat dipisahkan dari pengembangan konsep pembelajaran terpadu.

Kegiatan pembelajaran tematik dilaksanakan secara murni per mata pelajaran, yaitu hanya mempelajari standar kompetensi dan kompetensi dasar yang berhubungan dengan mata pelajaran (Asliana, 2017). Kompetensi yang digunakan untuk mengganti istilah standar dalam kurikulum 2013 adalah kompetensi inti dan kompetensi dasar. 
Bayu Purbha Sakti dan Sri Budiyono

PELAKSANAAN PEMBELAJARAN TEMATIK DI SDN 1 KRAGILAN

REFLEKSI EDUKATIKA : Jurnal Ilmiah Kependidikan 10 (1) Desember 2019. Hlm. 65-70

Dalam kurikulum 2013, pembelajaran tematik diterapkan di SD dari kelas I sampai kelas VI (Amanaturrakhmah et al, 2017). Namun kegiatan pembelajaran tematik memerlukan syarat yaitu on the implementation of thematic learning, teachers still need other references to deepen the material and to develop the ability of learners to be more independent in learning activities and tailored to the competencies that must be achieved (Yusrina, Yamtinah, dan Rintayati, 2018). Maksudnya ialah guru masih membutuhkan referensi lain untuk memperdalam materi. Guru mengembangkan kemampuan peserta didik agar lebih mandiri dalam kegiatan pembelajaran dan disesuaikan dengan kompetensi yang harus dicapai. Dalam pelaksanaan pembelajaran, tema yang diambil berhubungan dengan kehidupan sehari-hari sehingga akan memudahkan anak untuk memperoleh gambaran (Solekhah, 2014).

Hal ini disebabkan karena pembelajaran tematik masih belum dipahami sepenuhnya oleh pendidik. Kegiatan pembelajaran tematik dapat dilaksanakan untuk menunjang aspek kognitif, afektif dan psikomotor siswa. Siswa melakukan suatu kegiatan yang melibatkan aspek kognitif, afektif dan psikomotor sebagai suatu rangkaian tugas yang diberikan dalam rangka untuk mencari tahu atau mengeksplorasi tentang suatu tema yang sedang dibahas bisa kelompok atau individu (Karli, 2016).

Berdasarkan hasil observasi yang dilakukan penulis maka penelitian ini dilakukan dengan mengeksplorasi pembelajaran tematik sekolah dasar di daerah dekat perbukitan di Kecamatan Gantiwarno Kabupaten Klaten. Lokasi sekolah yang diteliti ditentukan berdasarkan lokasi yang mendekati daerah perbukitan. Sekolah dasar negeri yang dipilih adalah sekolah yang berada di dekat daerah perbukitan. Sekolah dasar negeri yang dipilih adalah sekolah yang sudah melaksanakan kurikulum 2013.

\section{METODE PENELITIAN}

Pendekatan penelitian yang digunakan adalah kualitatif. Tempat penelitian ini SDN 1 Kragilan. Data penelitian dikumpulkan dengan teknik observasi dan wawancara. Kegiatan yang dilakukan dalam teknik observasi adalah kegiatan pengamatan peneliti terhadap guru yang menjadi objek penelitian. Kegiatan yang dilakukan dalam teknik wawancara adalah wawancara dengan guru SDN 1 Kragilan.
Teknik analisis data yang digunakan meliputi fase reduksi data, penampilan data, dan verifikasi data. Pada fase reduksi data, peneliti mengurangi data dengan menghilangkan pernyataan berulang dan data tidak relevan. Pada fase penampilan data, peneliti mengumpulkan temuan melalui pemilahan dan perbandingan data, kode, dan kategori, dan mempertimbangkan tautan-tautan dengan tulisan memo. Pada fase verifikasi data, peneliti mengembangkan cerita yang menyampaikan gagasan utama dikembangkan dalam analisis data dan menyajikan cuplikan data atau cerita

\section{HASIL DAN PEMBAHASAN}

Hasil wawancara yang ditampilkan sesuai dengan petunjuk wawancara yang berkaitan dengan kegiatan pembelajaran tematik. Petunjuk wawancara yang dipilih yaitu wawancara guru mengenai pemahaman, persiapan, kesulitan yang dialami, dan cara mengatasi kesulitan dalam pembelajaran tematik. Penulis juga menambahkan hasil wawancara yang berkaitan dengan gempa bumi yaitu wawancara guru mengenai pemahaman gempa bumi, kesulitan yang dialami guru, dan cara menangani siswa ketika gempa bumi terjadi.

Ada perbedaan hasil wawancara guruguru dalam memahami mengenai pelaksanaan pembelajaran tematik. Ada 4 guru yaitu guru $\mathrm{HH}$, MS, DH, dan BS yang sudah bisa memahami pelaksanaan pembelajaran tematik. Ada 2 guru yaitu guru MW dan SA yang belum bisa memahami pelaksanaan pembelajaran tematik. Hasil wawancara yang dituliskan dan ditampilkan terhadap keempat guru yang sudah bisa memahami pelaksanaan pembelajaran tematik yaitu sebagai berikut:

"Pembelajaran tematik adalah pembelajaran yang diajarkan ke anak yang memadukan dari beberapa mata pelajaran yang dijadikan satu dalam suatu tema. Pembelajaran tematik bisa mengambil pembelajaran dari alam sekitar dan lingkungan sekolah serta berhubungan dengan kehidupan keseharian."

Ada kesulitan yang dialami guru-guru dalam melaksanakan pembelajaran tematik berdasarkan hasil wawancara. Semua guru yaitu guru MW, SA, HH, MS, DH, dan BS mengalami kesulitan dalam melaksanakan pembelajaran tematik Hasil wawancara mengenai kesulitan pembelajaran tematik yaitu sebagai berikut:

"Kami merasa kesulitan dalam menjalankan sistem penilaian pembelajaran tematik. Para siswa 
Bayu Purbha Sakti dan Sri Budiyono

PELAKSANAAN PEMBELAJARAN TEMATIK DI SDN 1 KRAGILAN

REFLEKSI EDUKATIKA : Jurnal Ilmiah Kependidikan 10 (1) Desember 2019. Hlm. 65-70

belum terbiasa menggunakan pembelajaran tematik. Materi pembelajaran tematik yang ditulis di buku kurang lengkap."

Hasil wawancara guru-guru mengenai solusi untuk mengatasi kesulitan dalam pelaksanaan pembelajaran tematik menunjukkan bahwa semua guru memiliki jawabannya. Semua guru yaitu guru MW, SA, HH, MS, DH, dan BS bisa menyelesaikan kesulitan dalam pelaksanaan pembelajaran tematik. Hasil wawancara mengenai solusi penyelesaian kesulitan pembelajaran tematik yaitu sebagai berikut:

"Kami saling berbagi dan bertukar berkaitan informasi, pengetahuan, dan pendapat dengan guru lain mengenai pembelajaran tematik."

Hasil observasi yang ditampilkan sesuai dengan petunjuk observasi dan berkaitan dengan kegiatan pembelajaran tematik. Petunjuk observasi yang dipilih yaitu observasi yang dilakukan di dalam kelas, di luar kelas, dan observasi mengenai buku teks tematik.

Hasil observasi yang dilakukan di dalam ruang kelas menunjukkan bahwa semua guru telah melaksanakan kegiatan pembelajaran tematik. Semua guru yaitu guru MW, SA, HH, MS, DH, dan BS sudah melakukan pembelajaran tematik di dalam ruang kelas masing-masing. Guru-guru tersebut melakukan kegiatan pembelajaran tematik di dalam ruang kelas dengan menata meja- meja dan kursi- kursi di dalam ruangan kelas. Guru MW kelas atas menggeserkan meja dan kursi untuk membentuk huruf $\mathrm{u}$ di dalam ruang kelas. Guru SA kelas bawah tetap menata meja dan kursi seperti semula dan sesuai kebiasaan keseharian. Guru $\mathrm{HH}$ kelas atas menggabungkan beberapa meja dan kursi sesuai kelompok yang dibentuk dan menghadap ke depan kelas. Guru MS kelas bawah tetap menata meja dan kursi seperti semula. Guru DH kelas atas menggeserkan meja dan kursi ke arah belakang kelas. Guru BS kelas bawah menggabungkan beberapa meja dan kursi sesuai kelompok yang dibentuk dan guru mendekatinya.

Pemahaman pembelajaran tematik dijawab para guru sesuai konsep pembelajaran tematik. Pembelajaran tematik adalah pembelajaran yang diajarkan ke anak yang memadukan dari beberapa mata pelajaran yang dijadikan satu dalam suatu tema. Pembelajaran tematik bisa mengambil pembelajaran dari alam sekitar dan lingkungan sekolah serta berhubungan dengan kehidupan keseharian.
Pemahaman pembelajaran tematik telah dijelaskan Okoro (2016) bahwa choosing a theme it mean teachers strive to connect the theme to the student's everyday life. Memilih tema berarti guru berusaha untuk menghubungkan tema dengan kehidupan seharihari siswa.

Pembelajaran tematik memiliki ketrampilan yang berpusat pada siswa (Puspita, 2016). Pembelajaran tematik dapat diambilkan informasi yang berasal dari lingkungan kehidupan siswa. Peran keluarga bisa memahamkan bagian materi dari pembelajaran tematik. Keluarga dan masyarakat memiliki peran juga demi keamanan anak usia sekolah dasar (Sakti, 2016b). Keamanan yang diciptakan dengan baik di dalam maupun di luar sekolah akan sangat mendukung dan menyukseskan tumbuh kembang anak sekolah dasar. Para siswa tentunya dapat belajar dengan nyaman tanpa ada gangguan dari apapun.

Ada beberapa kendala yang ditemui para guru dalam melaksanakan pembelajaran tematik. Para guru merasa kesulitan dalam menjalankan sistem penilaian pembelajaran tematik. Para siswa belum terbiasa menggunakan pembelajaran tematik.

Kesulitan mengajar pembelajaran tematik juga dialami oleh para guru yang sudah mengajar selama bertahun-tahun. Para guru diharuskan bisa memahami semua hal yang berkaitan dengan pembelajaran tematik. Para guru tersebut sudah bertahun-tahun mengalami perubahan kurikulum dan perubahan model pembelajaran tetapi hal tersebut harus memotivasi untuk menggunakan pendekatan tematik.

Pengalaman guru selama bertahuntahun bukanlah persyaratan untuk menggunakan dan tidak menggunakan pendekatan pembelajaran tematik dalam studi sosial. Studi sosial membutuhkan kompetensi sosial dan profesional. Kompetensi profesional adalah kamampuan penguasaan materi pelajaran luas mendalam (Sakti, 2016a). Kemampuan ini harus dimiliki oleh semua guru sekolah dasar. Guru yang memiliki kesulitan dalam meningkatkan kemampuan ini akan menemui kesulitan juga dalam mengembangkan keprofesionalannya dalam pembelajaran tematik.

Guru harus menjaga hal-hal yang menyulitkan dalam melakukan pembelajaran tematik. Guru jangan membiarkan berbagai bentuk ketidaksopanan terjadi di kelas (Sakti, 
Bayu Purbha Sakti dan Sri Budiyono

PELAKSANAAN PEMBELAJARAN TEMATIK DI SDN 1 KRAGILAN

REFLEKSI EDUKATIKA : Jurnal Ilmiah Kependidikan 10 (1) Desember 2019. Hlm. 65-70

2017a). Jika tindakan yang tidak sopan terjadi di dalam kelas maka hal itu akan menyulitkan bagi guru untuk mengelola atmosfir pembelajaran di dalam ruang kelas.

Guru sekolah dasar memiliki fungsi dan keahlian dalam menangani anak usia sekolah dasar (Sakti, 2019). Guru sekolah dasar akan menjadi biasa dalam menjaga anak yang berjumlah antara 15 sampai 30 anak dalam satu kelas. Hal tersebut membutuhkan banyak waktu dan kesabaran.

Para guru saling berbagi dan bertukar berkaitan informasi, pengetahuan, dan pendapat dengan guru lain mengenai pembelajaran tematik. Para guru juga mengusahakan untuk terus berkomunikasi dalam mendapatkan kreatifitas menyelesaikan permasalahan pembelajaran tematik.

Para guru yang memiliki banyak solusi akan menjadikannya guru yang berkualitas. Guru-guru berkualitas tinggi dipandang sebagai mereka yang secara teratur mengajukan pertanyaan, mengeksplorasi ide-ide, mengikuti perkembangan peluang penelitian dan pengembangan profesional, berbagi wawasan mereka dengan orang lain, bersemangat untuk bekerja dengan kolega dan mitra eksternal dalam proyek-proyek penelitian dan berupaya menerapkan ide di ruang kelas mereka. Beberapa penjelasan tersebut dapat dikemukakan sebagai berikut:

High-quality teachers are seen as those who regularly ask questions, explore ideas, keep up to date with research and professional development opportunities, share their insights with others, are eager to work with colleagues and external partners on research projects and seek to apply ideas in their classrooms (Grigg, 2015).

Para guru sekolah dasar diharapkan memiliki kemampuan untuk membaca, menyimak, menulis, mengolah, dan membicarakan informasi yang bersumber dari buku, internet, dan seminar (Sakti, 2018b). Informasi- informasi tersebut dapat dipergunakan untuk menemukan penyelesaian masalah yang dihadapi dalam mengajarkan pembelajaran tematik.

Penggunaan buku teks tematik yang menarik akan memotivasi para siswa sekolah dasar untuk lebih giat belajar. Konten materi yang ditulis dan digambar di dalam buku pelajaran akan mudah diingat siswa sekolah dasar (Sakti, 2018a). Buku pelajaran sekolah dasar yang digunakan siswa akan menentukan pola pikir siswa sekolah dasar.

Solusi mengembangkan pembelajaran tematik dapat dilakukan dengan menciptakan media pembelajaran dan mengembangkan sistem penilaian. Penciptaan media pembelajaran dan sistem penilaian dapat menstimulasi otak anak usia sekolah dasar (Moeloek, 2016).

\section{SIMPULAN}

Kesimpulan yang didapatkan dari penelitian yang dilakukan di sekolah dasar dekat area perbukitan yaitu sebagai berikut: Para guru sudah bisa memahami pembelajaran tematik. Pembelajaran tematik adalah pembelajaran yang diajarkan ke anak yang memadukan dari beberapa mata pelajaran yang dijadikan satu dalam suatu tema. Pembelajaran tematik bisa mengambil pembelajaran dari alam sekitar dan kehidupan keseharian. Para guru memiliki kendala dalam melaksanakan pembelajaran tematik. Para guru merasa kesulitan dalam menjalankan sistem penilaian pembelajaran tematik. Para siswa belum terbiasa menggunakan pembelajaran tematik. Para guru sudah memiliki solusi dalam pembelajaran tematik. Para guru saling bertukar informasi, pengetahuan, dan pendapat dengan guru lain mengenai pembelajaran tematik.

\section{DAFTAR PUSTAKA}

Ahyar, M., Farida, R. \&, \& Setiawati, A. 2016. Faktor-Faktor Kesulitan Guru Pada Pembelajaran Tematik Integratif Sekolah Dasar Di Kota Mataram. El-Hikan, IX (1): 1-24.

Amanaturrakhmah, I., et al. 2017. Manajemen Pembelajaran Tematik di Kelas Tinggi SD Percontohan Kabupaten Indramayu. Journal of Primary Education, 6 (2): 159-165.

Anshory, I., Saputra, S. Y., dan Amelia, D. J. 2017. Pelaksanaan Pembelajaran Tematik Sesuai Kurikulum 2013 Di SD Muhammadiyah 03 Wajak. ELSE: Jurnal Pendidikan Dan Pembelajaran Sekolah Dasar, 1 (1).

Asliana, A. 2017. Penerapan Konsep Pembelajaran Tematik Pada Pelajaran Matematika Sebagai Upaya 
Bayu Purbha Sakti dan Sri Budiyono

PELAKSANAAN PEMBELAJARAN TEMATIK DI SDN 1 KRAGILAN

REFLEKSI EDUKATIKA : Jurnal Ilmiah Kependidikan 10 (1) Desember 2019. Hlm. 65-70

Meningkatkan Hasil Belajar Siswa. Jurnal Global Edukasi, 1(3): 434-438.

Daniels, E. A. 2012. Fighting, Loving, Teaching (Vol. 4). Rotterdam: SensePublishers.

Grigg, R. 2015. Becoming an Outstanding Primary School Teacher. Becoming an Outstanding Primary School Teacher. New York: Routledge.

Karli, H. 2016. Penerapan Pembelajaran Tematik SD Di Indonesia. EduHumaniora | Jurnal Pendidikan Dasar Kampus Cibiru, 2 (1).

Karyani, L. T. 2017. Implementasi Pembelajaran Tematik Integratif Dengan Pendekatan Scientific Pada Kelas 5 Sekolah Dasar Negeri Unggulan Di Kabupaten Purworejo. E-Jurnal Skripsi Mahasiswa TP, 6 (8): 754-761.

Moeloek, N. F. 2016. Pedoman Optimasi Fungsi Otak Pada Pembelajaran Anak Usia Sekolah Di Tingkat Sekolah Dasar (SD)/Madrasah Ibtidaiyah (MI). Jakarta: Direktur Jenderal Peraturan PerundangUndangan Kementerian Hukum Dan Hak Asasi Manusia Republik Indonesia.

Mujiyono, Y. 2016. Penataran Kurikulum 2013 Klaten diikuti Ratusan Guru. Retrieved April 23, 2018.

Narti, Y., Setyosari, P., Nyoman Sudana Degeng, I., dan Dwiyogo, W. D. 2016. Thematic Learning Implementation in Elementary School (Phenomenology Studies in Pamotan SDN 01 and 01 Majangtengah Dampit Malang). International Journal of Science and Research, 5 (11).

Okoro. 2016. Teachers' Understanding And Use Of Thematic Approach In Teaching And Learning Of Social Studies In Rivers State, 4(3), 64-69.

Puspita, H. J. 2016. Implementasi Pembelajaran Tematik Terpadu Pada Kelas Vb SD Negeri Tegalrejo 1 Yogyakarta. BASIC EDUCATION, 5(9), 884-893.
Sakti, B. P. 2016a. Etika Dan Profesi Guru SD Di Tengah Perkembangan Zaman. Proceeding PGSD Universitas Kuningan 2016, 1(1), 99-107.

Sakti, B. P. 2016b. Indikator Sekolah Dasar Ramah Anak. Prosiding Seminar Nasional PKO FKIP UTP, 163-176.

Sakti, B. P. 2017a. Indikator Pengembangan Karakter Siswa Sekolah Dasar. Magistra Unwidha Klaten, 30, 1.

Sakti, B. P. 2017b. Persepsi Mahasiswa Program Studi Pendidikan Guru Sekolah Dasar Universitas Widya Dharma Tentang Etika Mahasiswa. Premiere Educandum: Jurnal Pendidikan Dasar Dan Pembelajaran, 7(02), 135.

Sakti, B. P. 2018a. Feasibility Indicators Of Study Books Used Elementary School Students. In Social, Humanities, and Educational Studies (SHEs): Conference Series. INA-Rxiv.

Sakti, B. P. 2018b. Training of Scientific Papers Writing On Students of Widya Dharma University. CARADDE: Jurnal Pengabdian Kepada Masyarakat.

Sakti, B. P. 2019. Training Writing Nonficial Stories In Students Of The PGSD Study Program Widya Dharma Klaten University. Jurnal Berdaya Mandiri, 1(1), 58-65.

Sakti, B. P., \& Wijayanti, W. 2014. Implementasi Pembelajaran Tematik Pada SDN Di Gugus III Kecamatan Kalasan Kabupaten Sleman DIY. Jurnal Prima Edukasia, 2(1), 14.

Solekhah, S. 2014. Implementasi Pembelajaran Tematik Di SD Muhammadiyah Program Khusus Surakarta. SOSIALITAS; Jurnal Ilmiah Pend. Sos Ant, 4(1).

Yusrina, H., Yamtinah, S., \& Rintayati, P. 2018. Implementation of Thematic Learning on Curriculum 2013 in 4th Grade Elementary School. IJPTE: International Journal of Pedagogy and Teacher Education, 2(0), 7. 